\title{
THE RESTRICTION OF HUMAN RIGHTS IN A PANDEMIC CRISIS: THE CASE OF UKRAINIAN LEGISLATION
}

\author{
Nadiia Kobetska ${ }^{1}$
}

Received: June 27, 2020 / Revised: October 14, 2020 / Accepted: November 18, 2020

(C) Association of Economists and Managers of the Balkans, 2020

\begin{abstract}
The presented paper is aimed at substantiating the formal and legal grounds for the introduction of restrictions on human rights in the battle against the spread of COVID-19 in Ukraine. The analysis of restrictive measures introduced by the Government of Ukraine is conducted by the author on the basis of their interpretation and comparison of Ukrainian legislative acts that define the legal regimes of quarantine, an emergency situation and a state of emergency. The author analyzes the problematic legislative provisions that formed the basis for the introduction of quarantine measures and an emergency situation in Ukraine and established restrictions on the implementation of a number of the constitutional rights of citizens. The article substantiates the conclusion on the constitutionality and legality of restrictions on human rights under a state of emergency, which was not introduced in Ukraine.
\end{abstract}

Keywords: Covid-19, Human Rights, Quarantine, Emergency Situation, State of Emergency.

\section{JEL Classification K38}

nadiia.kobetska@pnu.edu.ua

1 Vasyl Stefanyk Precarpathian National University, 57, Shevchenko Str., Ivano-Frankivsk, 76018, Ukraine 


\section{INTRODUCTION}

The current global pandemic crisis has led to the introduction of emergency measures by states to protect the lives and health of the population. They, in turn, have led to significant restrictions on the normal functioning of society and human rights. The legitimacy and justification of restrictions on human rights, especially in emergencies, are complex and delicate issues. Today in Ukraine, the response to the emergency situation related to the spread of Covid-19 occurs in complex political (war in Eastern Ukraine, immaturity of political forces), economic (low efficiency of production, low income level, budget deficit), socio-cultural conditions (high unemployment, public distrust of the authorities, low level of legal culture). In addition, the legal system of the state is not properly formed. It is characterized by complexity, contradictions, the variability of legislation, the imbalance of the judicial system, lack of effective mechanisms of control and responsibility for the implementation of legal requirements. In such circumstances, the issue of the legality of restrictive measures is of particular importance.

\section{ANALYSIS AND DISCUSSION}

Ukraine is a member of the World Health Organization. It signed and committed to the International Health Regulations of 2005. It is the latest document that defines international mechanisms to combat the spread of diseases. Researchers, analyzing the corresponding regulations, emphasize their importance for organizing the battle against the increasing transnational threats of infectious diseases (Baker, \& David, 2006; Agrawal, 2007; Von Bogdandy, \& Villareal, 2020). Nevertheless, the main role in risk management in the state is played by national legislation and national authorities.

Ukrainian legislation that defines the mechanism for the protection of public health, including that from infectious diseases, includes a number of legislative acts, namely: Fundamentals of the Legislation of Ukraine on Health Care (1993), the Law of Ukraine „On Ensuring Sanitary and Epidemic Safety of the Population” (1994), the Law of Ukraine „On Protection of Population against Infectious Diseases" (2000) and dozens of regulations adopted to specify the main provisions of the law. The latter include, in particular, the Regulations on Sanitary Protection of the Territory of Ukraine (2011), developed on the basis of International Health Regulations.

Table 1. Quarantine - an emergency situation - a state of emergency

\begin{tabular}{|l|l|l|l|}
\hline $\begin{array}{l}\text { Grounds for } \\
\text { comparison }\end{array}$ & Quarantine & Emergency situation & State of emergency \\
\hline $\begin{array}{l}\text { Legislative } \\
\text { regulation }\end{array}$ & $\begin{array}{l}\text { the Law of Ukraine } \\
\text { "On Protection of } \\
\text { Population against } \\
\text { Infectious Diseases" }\end{array}$ & $\begin{array}{l}\text { The Code of Civil Protection } \\
\text { of Ukraine }\end{array}$ & $\begin{array}{l}\text { the Law of Ukraine "On the } \\
\text { Legal Status of a State of } \\
\text { Emergency" }\end{array}$ \\
\hline $\begin{array}{l}\text { Grounds for } \\
\text { implementation }\end{array}$ & $\begin{array}{l}\text { the risk of the spread } \\
\text { of infectious diseases }\end{array}$ & $\begin{array}{l}\text { catastrophe, accident, fire, } \\
\text { natural disaster, epidemic } \\
\text { or other emergency that has } \\
\text { caused (may cause) a threat to } \\
\text { life or health, a large number } \\
\text { of the dead and affected, } \\
\text { significant material damage, } \\
\text { etc. }\end{array}$ & $\begin{array}{l}\text { man-made or natural } \\
\text { disasters at national level } \\
\text { that have led or may lead to } \\
\text { human and material losses, } \\
\text { pose a threat to citizens' life } \\
\text { and health; an attempt to } \\
\text { seize state power or change } \\
\text { the constitutional order of } \\
\text { Ukraine through violence }\end{array}$ \\
\hline
\end{tabular}




\begin{tabular}{|c|c|c|c|}
\hline $\begin{array}{l}\text { Who } \\
\text { implemented }\end{array}$ & $\begin{array}{l}\text { the Cabinet of } \\
\text { Ministers of Ukraine }\end{array}$ & $\begin{array}{l}\text { the Cabinet of Ministers } \\
\text { of Ukraine, regional state } \\
\text { administrations (on their } \\
\text { territories) }\end{array}$ & $\begin{array}{l}\text { declared by the Decree of the } \\
\text { President of Ukraine, which } \\
\text { is subject to approval by the } \\
\text { Verkhovna Rada of Ukraine } \\
\text { within two days from the date } \\
\text { of the address of the President } \\
\text { of Ukraine }\end{array}$ \\
\hline $\begin{array}{l}\text { Territory } \\
\text { affected }\end{array}$ & $\begin{array}{l}\text { determined by the } \\
\text { Cabinet of Ministers } \\
\text { of Ukraine }\end{array}$ & $\begin{array}{l}\text { the whole territory of the } \\
\text { state or its separate areas }\end{array}$ & $\begin{array}{l}\text { the whole territory of the } \\
\text { state or its separate areas }\end{array}$ \\
\hline $\begin{array}{l}\text { Response } \\
\text { measures }\end{array}$ & $\begin{array}{l}\text { preventive, anti- } \\
\text { epidemic and other } \\
\text { measures }\end{array}$ & $\begin{array}{l}\text { the introduction of a special } \\
\text { procedure for interaction } \\
\text { between subjects of civil } \\
\text { defense to prevent and } \\
\text { eliminate the consequences of } \\
\text { emergencies }\end{array}$ & $\begin{array}{l}\text { emergency measures, the } \\
\text { exhaustive list of which is } \\
\text { established by law }\end{array}$ \\
\hline $\begin{array}{l}\text { Restrictions on } \\
\text { human rights }\end{array}$ & $\begin{array}{l}\text { the possibility } \\
\text { of restricting the } \\
\text { rights of individuals } \\
\text { and legal entities; } \\
\text { introduction } \\
\text { of additional } \\
\text { responsibilities }\end{array}$ & \begin{tabular}{|l|} 
The Code of Civil Protection \\
of Ukraine does not contain \\
provisions on the restriction \\
of human rights and only \\
defines the powers of subjects \\
of civil defense, some of \\
which relate to restrictions \\
on rights (for example, \\
restriction or prohibition of \\
vehicle movement, entry into \\
the emergency zone, etc.)
\end{tabular} & $\begin{array}{l}\text { the possibility of restricting } \\
\text { the constitutional rights } \\
\text { of citizens defined by } \\
\text { law; forced imposition of } \\
\text { additional responsibilities }\end{array}$ \\
\hline
\end{tabular}

March 11, 2020, the Cabinet of Ministers of Ukraine by its resolution on the basis of Art. 29 of the Law of Ukraine „On Protection of Population against Infectious Diseases” introduced quarantine measures throughout Ukraine. On March 16, 2020, it was amended and the list of measures and prohibitions was expanded. In the meantime, the city of Kyiv and several oblasts (Ukraine's administrative units) declared an emergency situation on their territories, which was extended to the entire territory of Ukraine by the order of the Cabinet of Ministers of Ukraine on March 25, 2020. At the official level, the option of declaring a state of emergency was also considered, but it was not implemented. Each of these legal regimes has its own characteristics and is governed by its own legal documents (their comparison is presented in Table 1).

In fact, these restrictions have been the subject of heated debate. The main issue is the question of the relationship (compromise) between the protection of people's health and the restriction of the exercise of their rights. Gostin, \& Berkman (2007), analyzing the specifics of pandemic control measures, emphasized that ,multiple, targeted approaches are likely to be most effective, but they can have deep adverse consequences for the economy and civil liberties" (p. 141). The importance of respecting human rights, democracy and the rule of law in the context of the battle against the pandemic is indicated in the Information Document: Respecting democracy, rule of law and human rights in the framework of the COVID-19 sanitary crisis (2020) - a document approved by the Secretary General of the Council of Europe.

The Convention for the Protection of Human Rights and Fundamental Freedoms (1950) in Art. 8, 9, 10,11 allows the possibility of interfering with the basic human rights ,for the protection of health or morals or for the protection of the rights and freedoms of others". Art. 15 of the Convention contains the following provision: „In time of war or other public emergency threatening the life of 
the nation any High Contracting Party may take measures derogating from its obligations under this Convention to the extent strictly required by the exigencies of the situation, provided that such measures are not inconsistent with its other obligations under international law". The Constitution of Ukraine establishes the rule that ,the constitutional rights and freedoms of a person and a citizen shall not be restricted, except in cases provided by the Constitution of Ukraine. Under the conditions of martial law or a state of emergency, certain restrictions on rights and freedoms may be established, with their terms indicated. The rights and freedoms provided in Art. 24, 25, 27, 28, 29, $40,47,51,51,55,56,57,58,59,60,61,62,63$ of this Constitution shall not be restricted" (Art. 64). Art. 33, 34, 35, 36, etc. of the Constitution of Ukraine allow for the possibility of restricting rights „for the purpose of protecting the health of the population” and „in accordance with the Law.”

Researchers (Gostin, \& Berkman, 2007, pp. 147-150; Christoffersen, 2009; Barak, 2012; Dakhova, 2018) substantiate a number of provisions and principles that should underlie decisions on the restriction of individual human rights, based on the practice of European Court of Human Rights. Without going into detailed scientific and theoretical analysis, three basic principles can be singled out: 1) for the legitimacy of interference with human rights, it is necessary for the possibility of such interference to be envisioned by law, provided that this law establishes the grounds and the procedure for introducing such restrictions in a clear, detailed and exhaustive manner; 2) the restriction of rights is put in place in order to achieve a legitimate goal on the grounds of public necessity; 3 ) in the process of the introduction of restrictions the principle of proportionality between the reached result and the caused damage is observed.

The fact of the danger of the spread of coronavirus and its critical consequences for the life and health of the population today is beyond doubt. Therefore, we will not discuss the validity and social necessity of introducing restrictive measures in modern conditions. More questions arise about the content of Ukrainian legislation that has led to the introduction of special measures, including those related to the restriction of human rights. In this context, let us consider the analysis of the laws in Table 1.

The formal and legal basis for the introduction of quarantine throughout Ukraine in the Government Resolution is Art. 29 of the Law of Ukraine „On Protection of Population against Infectious Diseases”. In the meantime, based on a systemic interpretation of the articles of this Law, it seems to refer to quarantine only in certain areas and not within the whole state and provides local authorities with additional powers in the areas where it is established. In addition, Art. 29 does not contain detailed instructions on the procedure and conditions for the restriction of human rights but only indicates such a possibility. The regime of an emergency situation (which is also introduced in Ukraine) in accordance with the Code of Civil Protection of Ukraine means increased readiness and coordination of state and local authorities that includes strengthening public order, informing citizens, disinfection of facilities and territories, etc. Nevertheless, the Code of Civil Protection of Ukraine also does not establish the procedure and conditions for restricting the rights of citizens. In addition, Art. 37 of the Code of Civil Protection of Ukraine establishes the provisions on declaring quarantine as a measure to respond to an emergency situation (after it is declared).

Another law is the Law of Ukraine „On the Legal Status of a State of Emergency”. Its norms establish mechanisms of action in case of a real threat to the safety of citizens and define in detail the types of restrictive measures that may be introduced. Researchers characterize it as a mandatory component of the national security system (Kovaliv, Rutar, \& Pavlyshyn, 2015). It contains the list of rights that may be restricted, the list of measures that may be taken by state bodies. In addition, it is introduced by the Verkhovna Rada of Ukraine in the form of a law defining restrictions on human rights. The state practice of Ukraine has an example of the introduction of a state of emergency in 
connection with the disease of highly pathogenic avian influenza in a number of the districts of the Autonomous Republic of Crimea in 2005.

It is considered that the imposition of quarantine measures and restrictions on human rights in the battle against the spread of COVID-19 after a state of emergency is declared would be right and consistent with the Constitution of Ukraine. However, in Ukraine, in light of a conflicted relationship between political and social processes, the authorities were not ready to impose a state of emergency, which most citizens associate with dictatorial rule. Today, the actions of the Ukrainian authorities and the legality of the implementation of a number of measures are criticized in terms of formal and legal grounds. In addition, a number of restrictions were not clearly stated in the orders of the Government. These include, for instance, ,involuntary hospitalization of patients with COVID-19”, the mechanism of which is not defined by Ukrainian law; ,,prohibition of staying in public places without wearing personal protective equipment" to explain the concept of ,public place” and others. Human rights organizations record and publish unreasonable, in their opinion, restrictions on human rights, violations by representatives of law enforcement agencies during the introduction of quarantine restrictive measures (Typovi porushennia, 2020a; Typovi porushennia, 2020b).

\section{FUTURE RESEARCH DIRECTIONS}

The pandemic caused by COVID-19 has become a serious challenge for the whole world. The Ukrainian authorities organized themselves as quickly as possible to develop and implement measures to prevent a rapid spread of the infection. The result of the timely introduction of quarantine restrictive measures presented a satisfactory picture of the morbidity of the population. In the meantime, the quarantine measures applied were objectively related to interference with human rights, their restriction and impossibility of realization. The validity and legitimacy of such restrictions are the subject of serious discussion for all structures of civil society. Analysis of research by Ukrainian legal scholars gives grounds to speak about the lack of theoretical and legal generalizations and conclusions about the mechanism for legal regulation of situations similar to the current ones. The practice of applying the current legislation of Ukraine has shown its loopholes and deficiencies. This has called into question the legitimacy of a number of measures. It can be predicted that the law-making and law-enforcement practices of recent months related to human rights restrictions will be the subject of analysis from various perspectives:

- by sociologists and political scientists - in terms of the influence on the functioning of civil society, the state and the political system of Ukraine;

- by legal scholars - in terms of a study of the proportionality, validity and legitimacy of the measures taken;

- by human rights defenders - in terms of substantiating violations of rights and appeals to the court to restore the violated rights and receive compensation for damage;

- by the judicial system - in the context of legal assessments of specific situations;

- by lawmakers - in order to make changes and amendments to legislation, etc.

The result of joint work should ultimately be the improvement of the legislative mechanism for the protection of life and health of the population of the state from dangerous infectious diseases.

\section{CONCLUSION}

To counter the spread of COVID-19 coronavirus in Ukraine, the authorities have introduced quarantine measures throughout the country and declared an emergency situation. The objective global picture of the spread of the disease has led to the introduction of special quarantine meas- 
ures, some of which have limited the ability of citizens to exercise a number of constitutional rights. The legitimacy and validity of restrictions on human rights are extremely important for the existence of democracy and the rule of law. In Ukraine today, the issue of compliance with the formal and legal grounds for imposing such restrictions is hotly debated. Despite the objective justification of the application of such measures, the procedure for their implementation does not fully comply with the international legal framework for the regulation of human rights and the Constitution of Ukraine. Such restrictions would be absolutely legal in a state of emergency, which the Ukrainian authorities did not impose in the current socio-political conditions. The current situation has also shown a number of deficiencies in the corresponding legislative regulation and the need to improve it.

\section{REFERENCES}

Agrawal, V. K. (2007). Pandemic Response and International Health Regulations. Medical Journal Armed Forces India, 63 (4), 366-367. https://doi.org/10.1016/S0377-1237(07)80018-9

Baker, M. G., \& David, P. F. (2006). Global Public Health Surveillance under New International Health Regulations. Emerging Infectious Diseases, 12 (7), 1058-1065. doi: 10.3201/eid1207.051497

Barak, A. (2012). Proportionality: Constitutional Rights and their Limitations. New York: Cambridge University Press. https://doi.org/10.1017/CBO9781139035293

Christoffersen, J. (2009). Fair Balance, Proportionality, Subsidiarity and Primarity in the European Convention on Human Rights. Leiden/Boston: Martinus Nijhoff Publishers. https://oi. org/10.1163/ej.9789004170285.i-670.2

Dakhova, I. (2018). Obmezhennia realizatsii prav i svobod liudyny: konstytutsiine rehuliuvannia ta praktyka Yevropeiskoho Cudu z prav liudyny [Limitation of the Implementation of Human Rights and Freedoms: Constitutional Regulation and Practice of the European Court of Human Rights]. Forum Prava, 4, 17-25. http://doi.org/10.5281/zenodo.1467599

Gostin, L., \& Berkman, B. (2007). Pandemic influenza: ethics, law, and the public's health. Administrative Law Review, 59 (1), 121-175.

Information Document: Respecting democracy, rule of law and human rights in the framework of the COVID-19 sanitary crisis (2020). Retrieved from https://www.coe.int/en/web/portal/-/coronavirus-guidance-to-governments-on-respecting-human-rights-democracy-and-the-rule-of-law

Kovaliv, M., Rutar, A., \& Pavlyshyn, Yu. (2015). Poriadok i pidstavy vvedennia pravovoho rezhymu nadzvychainoho stanu [The order and the grounds of the legal regime of emergency state]. The Scientific Bulletin of Lviv State University of Internal Affairs: legal series, 2, 180-188.

Typovi porushennia prav liudyny predstavnykamy orhaniv pravoporiadku $v$ khodi vprovadzhennia karantynnykh obmezhen: Periodychnyi zvit [Typical human rights violations by law enforcement agencies during the implementation of quarantine restrictions: Periodic report] (2020a). Retrieved from https://drive.google.com/file/d/1m0j6VjLMyMQSArLKZ8nja6Flc3_i0CvD/ view

Typovi porushennia predstavnykiv orhaniv pravoporiadku pid chas zaprovadzhennia karantynnykh obmezhuvalnykh zakhodiv: Periodychnyi zvit [Typical human rights violations by law enforcement agencies during the implementation of quarantine restrictions: Periodic report] (2020b). Retrieved from https://drive.google.com/file/d/1581Cs7tW6mQcCzmZ59nysVROFlEUeuYL/view

Von Bogdandy, A., \& Villareal, P. (2020). International Law on Pandemic Response: A First Stocktaking in Light of the Coronavirus Crisis. Max Planck Institute for Comparative Public Law \& International Law, Research Paper No. 2020-07. Retrieved from https://papers.ssrn.com/sol3/ papers.cfm?abstract_id $=3561650$ 